\title{
La Recherche
}

Genre et rapports sociaux dans les espaces lusophones

Gênero e relações sociais nos espaços lusófonos

Gendered social relationships in Portuguese-speaking spaces

Dossier thématique sous la direction de

Marissa Moorman \& Kathleen Sheldon 


\section{GENDER IN THE LUSOPHONE WORLD History, Identity and Nation}

$\mathrm{T}$ he dynamic state of Lusophone studies was amply demonstrated by the enthusiastic response to the call for papers for this special dossier. Indeed, scholarship on the lusophonic world reflects trends within the academy more broadly, while offering insights grounded in the specificities of the past and present politics of lusophonic spaces. Over one hundred scholars wrote to express an interest in the topic, and over seventy of those submitted papers for our consideration. The diversity of work received by junior and senior scholars underscores the significance of gender as an analytical category and as an area of scholarly interest, as well as emphasizing its political import. We were overwhelmed, but happily so, by this outpouring of excellent research and writing on women and men, identities and memories, family and work, politics and history, literature and art, on every corner of the Lusophone world. The limited number we chose to include allows us to focus on some of the shared characteristics. But comparison should also underscore contradictions and difference (for example, in colonial policy), opening up space for alternative outcomes and expressions.

Participants in recent debates about the reality or importance of the Lusophone community have suggested that such a community is fragile, based only on a shared language and disparate experiences of Portuguese colonialism. In Africa alone it has been argued that Mozambique and Angola have more in common with other southern African nations than they do with the West African nations of Guinea-Bissau and Cape Verde, and such connections as do exist become even more tenuous when looking at the far-flung nations and territories of Brazil, Goa, Macau, and East Timor. Including the metropole of Portugal itself, which obviously did not share the common experience of being colonized, underscores the idea that it is sometimes a stretch to write about the Lusophone world as a coherent entity ${ }^{1}$. At the same time, countries who share the Portuguese language have made much progress in recent years in developing the connections among themselves, as noted in the revitalization of the Comunidade dos Paises de Lingua Portuguesa, CPLP2 ${ }^{2}$. Such an organization highlights the ways in which communities, identities, and social relations are not only about location, but are also based on historical processes, shared linguistic resources, economic interests, and cultural practices that create new geographies of affinity and politics of association in the present. The articles in this dossier confirm that community may be as much about difference and change as it is about similarity and continuity.

The fourteen articles that form this special dossier on gender in the Lusophone world represent a series of themes and analyses present in the over seventy

${ }^{1}$ Edward AlPERs, «Studying Lusophone Africa: Retrospect and Prospect», Ufahamu, XXIII (3), 1995: 94-109.

${ }^{2}$ See the CPLP website at <http:www.cplp.org $>$. 
submissions received. Temporally they range from the 16th century to the present while geographically they span the globe following the trajectories of both Portuguese exploration and conquest as well as those of its subalterns whose past and present migrations, modes of life, and memories simultaneously talk back to and complicate that legacy. Yet, this dossier does not pretend to be comprehensive. There is little here that registers the developments in gender theory on the question of sexuality. Quinlan and Arenas' Lusosex (2002) ${ }^{3}$ deftly demonstrates the relevance of this area of study to lusophonic studies, opening the field for further investigation rather than being the last word on the subject. While sexuality may be a blind spot in this dossier as a whole, it does indeed inhabit some of these works even if it is not a central category of analysis (see articles by Havik, Melo, and Massart). Specific themes in this dossier include, and limn the complexities of, memory, migration, work, violence, the nation, and colonial encounters. The concerns and methodologies that dominate one article echo and resonate in others whose distance temporally and geographically might otherwise seem unbridgeable but is traversed through a notion of lusophonia.

We have grouped the articles in two broad sets in order to intensify potential resonances, introduce echoes and push the boundaries of one piece with the different concepts and geo-temporalities of the others: «Memory, Migration and Colonial Encounters» and «Gender at Home, at Work, and in the Nation». While we will explain the logic that compelled this organization below, it is worth remembering that these groupings of articles are really only suggestions and that, following the insights of queer theory, we encourage promiscuous reading strategies that re-map the boundaries imposed by editorial and other authorities.

\section{Memory, Migration and Colonial Encounters}

The first set of articles all deal with the gendered politics and practices of colonialism broadly cast. Like the innovative recent work on colonialism, these articles further the argument that colonization was neither monolithic nor wholly determined by the colonizer, who was as much product as producer. Indeed, colonialism was a process not an event, made of many encounters and not just one discrete encounter. The many contemporary gendered struggles, relations, and discourses that structure the dossier's second section point to the fact that such processes are not neatly contained relics of the past and that the complex dynamics of structure and agency so central to colonial life, both at the material level and in terms of representation, continue to be a site of struggle.

The conflicts, contours and continuities of colonialism were made on the ground and in the interaction of local peoples, or insiders, and practices with foreign peoples, or outsiders, and practices. In fact, the articles in this section implicitly elaborate what Frederick Cooper and Ann Laura Stoler tagged the «Tensions of Empire» and specify them for the lusophonic world ${ }^{4}$. Gender is not peripheral

\footnotetext{
3 Susan Canty Quinlan \& Fernando Arenas (eds), Lusosex, Minneapolis, University of Minnesota, 2002.

${ }^{4}$ Ann Laura Stoler \& Frederick Cooper (eds), Tensions of Empire, Berkeley, University of California, 1997.
} 
but rather central to the processes of colonization and to the tensions of empire. And yet, it is not a stand-alone category. The richness of analysis in these articles, and the complexities they reveal, re-affirms that gender (like race and class, among others) is fundamentally about power and about relations that are often more complex than just the social relations associated with the categories «man» and «woman». Gender is imbricated with, and garners meaning in relation to, the axes of race, class, generation, nation, location, and sexuality. At the same time, a gendered analysis may also consider gender at the level of representation, such that gendered language and gendered images represent and produce relations of power and not necessarily, or not only, specific relations between men and women (or men and men, women and women), although such relations are almost always implicated.

This section begins with Claudia Pazos-Alonso's succinct analysis of a collection of short stories by the Lisbon-based Cape Verdean writer, Orlanda Amarilis, in which she explores the complexities of Cape Verdean metropolitan lives on the eve of the 1974 revolution in Portugal. Pazos-Alonso shows how Amarilis gently but powerfully indicts the romance of lusotropicalism with the eye-opening revelations regarding race and gendered markers of difference. Pazos-Alonso suggests that: "Amarilis arguably uses the depiction of the subaltern position of women, in a society predicated upon asymmetrical gender roles, as a magnifying lens to question unequal power relations between colonizers and colonized». Her suggestion serves as an apt opening for the rest of the articles in this section.

The works by Florence Pabiou-Duchamp, Philip Havik and Leonor Pires Martins move back in time and over space from the psychic destabilization of some metropolitan elite Cape Verdeans on the eve of the revolution in Portugal to the scene of production of the very colonial categories and practices that Amarilis exposes. In different ways, Pabiou-Duchamp, Havik and Martins show the production of those categories to be fragile, contingent, and profoundly gendered. Pabiou-Duchamp revisits the other cusp of the long colonial encounter - precolonial commercial and political relations of the Zambezi polities of Karanga with Portuguese traders and representatives of the Portuguese crown. «Être femme de rois karanga à la fin $\mathrm{du} \mathrm{xvI}^{\mathrm{e}}$ et au début du $\mathrm{xvII}^{\mathrm{e}}$ siècles» demonstrates that what 16th and 17th century observers and 20th century historians understood to be an «honorific title» («femme du roi») bestowed upon some locally-based Portuguese was far more complex. By going beyond titles interpreted through narrow, masculinist, European-based notions of royal power to explore the gendered representational politics of the Karanga royalty, Pabiou-Duchamp also highlights the centrality of women to the functioning of the political system.

Havik's «Les Noirs et les «blancs» de l'ethnographie coloniale. Discours sur le genre en Guinée portugaise (1915-1935)», explicitly explores the gendered tensions of empire. He exposes the thinness of colonial administrator-generated anthropology for representing society in Guinea while, in essence, arguing that works from this period often show us much more about the interests of the «colonizer» than about the daily life and society of the «colonized». Havik argues effectively, through his close-reading of a variety of published and archived ethnographic sources, that a focus on the local administrators reveals «a structuring element that intersected vectors such as power and nation with gender and racial preconceptions» and was at the base of the production of colonial tropes. Havik both 
shows how those tropes changed over time (from images of ideal ethnic and racial types of African women to women as mothers within in a larger bio-medical discourse of empire) and had, at least initially, different models: European ones for men and African ones for women.

If Havik focuses on the representational interface of the colonizer/colonized relationship, Leonor Pires Martins «Menina e moça em África. Maria Archer e a literatura colonial portuguesa», moves us into the gendered spaces of the metropole and of the production of colonial literature. She shows the ways in which the writer Maria Archer consciously worked against the gendered stereotypes of colonial literature and the poetics of empire that emphasized «as acções de figuras masculinas e elidiram, ou pelo menos marginzalisaram, a participação das mulheres» («the actions of masculine figures and elided, or at least marginalized, the participation of women»). But by focusing on Archer's consciousness of gender, Martins does more than just valorize or recover female agency, she uses female subjectivity and a feminist consciousness to point to the very gendered nature of colonial culture and politics both in the metropole and, by extension, in the colonies.

Susana Pereira Bastos' study, "'Hierarchical Alterity is a Mere Illusion": Some Reflections on the Creative Power of Women's Expressive Traditions in the Portuguese-Speaking Hindu Diaspora», moves between colony and metropole and through the dichotomy of colonizer/colonized to the Portuguese-speaking Hindu communities of Mozambique, Portugal and the United Kingdom. Pazos-Alonso implies that Amarilis' work shows migration to instead be displacement. This interpretation echoes in Bastos' piece where the emphasis is not so much on the revelation of difference but its negotiation through women's expressive practices. Gendered practices help traverse ethnic, spiritual and racial difference not to mention (dis)location.

Finally, Marguerite Itmar Harrison analyzes how two Afro-Brazilian women artists confront gendered colonial legacies in Brazil in her article: "Through the Eyes of Brazil's African Daughters: Vision and Memory in the Artwork of Rosana Paulino and in the Short Fiction of Marilene Felinto». Harrison argues that Marilene Felinto's short fiction and Rosana Paulino's artwork employ personal memory for collective redemption in the context of a contemporary Brazilian society characterized by inequalities entwined with race, class, gender, and location (rural and urban). Re-membering in the work of Felinto and Paulino, Harrison asserts, uses memory to reconnect and mobilize the past for work in the present. While colonialism may seem most remote in this piece, it is precisely here where we see that it is a process that marks the present, and this is worth remembering as we move into the next section.

\section{Gender at Home, at Work, and in the Nation}

The second set of articles address a range of experiences related to gender in the home, at work, and in the nation. Each locale, though geographically distant from the others, includes people who forcefully define themselves. At times the variety of situations, from rural women in Angola undergoing initiation rites to urban men in East Timor who are wrestling with their relationship to the violence around 
them, might obscure the connections between these studies, yet they all are cognizant of their relationship to Portugal and the Lusophone community.

The young Handa of Angola in Rosa Melo's contribution «Mulher é aquela que "comeu o boi". O efuko e a construção do généro no grupo étnico Handa» participate in an initiation rite which confers adult status on girls. The physical imperfection that is associated with uncircumcised Handa is related to deficiencies in society, as that person is seen as a source of filth and as a troublemaker. Thus a woman's self identity is intricately intertwined with her community. Gender identity is also related to the physical body, whether it is changed through the course of the initiation rites, or as other articles describe, through pregnancy, political activism, or violence.

The pregnant adolescents of Pina in Recife, Brazil, told Véronique Durand: Grossesse à l'adolescence. Une population dans la marge sociale à Recife, (Brésil) that they did not like the term «pregnant teenager» and their own choice was that they be called «As Rosas da Pina», The Roses of Pina. Durand demonstrates that these young people made a decision to become pregnant, and that it was not a random or accidental event as has often been depicted. Likewise in Maristela de Paula Andrade's article about Brazil's Nordeste, «Mutirões, empates e greves. Divisão sexual do trabalho guerreiro entre famílias de quebradeiras de coco babaçu, no Brasil», the activists have defined for themselves who they are and how to understand their political actions. They rejected ideas that peasant women would be passive and accepting, and introduced reforms that allowed the community as a whole to have greater access to local resources and more control over their work environment. The women's activities formed the basis of the development of a local community, as women activists made public efforts to improve their situation.

The women of the elite business families of Lisbon claimed they were not housewives (dona da casa), but rather family managers (gestora familiar). In «Hommes d'affaires et gestionnaires familiales : complémentarités et asymétries de genre dans une élite de Lisbonne», Antónia Pedroso de Lima found that those women were an integral part of the business and the family, and they did not accept the popular image of donas da casa as being lazy or not working. As Lima demonstrates, the worlds of finance and business where male family members hold sway rely heavily on the family relationships that women develop and maintain. Although a gender division of labor is prominent, the division reflects a complementarity, and men and women recognize the central role that both sexes and their notreally-separate spheres play in the success of their business and their homes. An important aspect of the adult gender division was found in the ways that boys and girls were raised, observing and participating in their parents' activities. Women remembered assisting their mothers plan important social events, while men recalled watching their fathers as they did the work of their business.

The changes found in subsequent generations of women are also delineated. More women of the younger generations finish their schooling, though they are still expected to focus their energies on the home. But one young woman interviewed by Lima was determined to enter into the family business at a leadership level. Family members told her she would be able to «help her brother» in the 
business, but at age 18 she had a plan that she hoped would allow her to take part in the business itself. The new generation of young women continues to struggle to alter the existing ideas about women's place within the family business.

The connection with the Handa girls learning their mothers' roles in Handa society, marked by a particular rite, is brought out by the juxtaposition of the articles here. The Lima article on women in Lisbon also relates to Ana Bénard da Costa's paper, which describes the interconnection of women's work and family life in the poor neighborhoods that surround Maputo, Mozambique ("Género e poder nas famílias da periferia de Maputo»). Though at nearly the opposite end of the social and economic spectrum from the lisboetas, the Maputo women's experiences also illustrate how the interrelation of family structures has an impact on women's work. In Mozambique families are formed through a variety of legal and customary rituals and passages, so that women and men together determine whether to describe themselves as married or otherwise in a relationship, and to define that relationship. The continuation of polygyny and women's work in local small-scale marketing both contribute to the ways in which urban women identify themselves within the larger society.

A further expansion on how Lusophone women define themselves is found in Isabel Fêo Rodrigues's article on ethnicity in Cape Verde, "“Our Ancestors Came from many Bloods": Gendered Narrations of a Hybrid Nation». The stories people remembered and told about their families reflected the location of the nation of Cape Verde as being somewhere between Portugal and Africa. As with many stories of national origin, the first woman in the genealogy is crucial to later interpretations of ethnicity and identity. As Cape Verdeans all came from somewhere else, many have selected their own off-island identity in ways that improve upon the (presumed) reality of colonial conquest and subjugation.

Two articles in this section discuss Lusophone masculinities, in these cases, both in small locations marked by dramatic events. In «Occupation, Resistance, Dominance and Patriarchy. Notes on Masculinities, Violence and Power in Timor Leste», Henri Myrttinen outlines the changing relationship of men to violence in East Timor, and demonstrates how the colonial history, especially the years of subjugation to Indonesia, contributed to men identifying with violent activity as a mark of masculinity. In a sense, there developed an «ideal» Timorense man, and that man was given to violent and aggressive behavior. While such behavior might have had some grounding in the long armed struggle for independence, Myrttinen also shows that it can be difficult to shift the preferred male disposition to a less violent characteristic.

In the second article on masculinity «Masculinités pour tous? Genre, pouvoir et gouvernementalité au Cap-Vert. Le foyer dans la spirale de l'ouverture et du changement à Praia », Guy Massart also suggests that there was an idea of an ideal man in Praia, Cape Verde, but that this paradigm has changed under the impact of increased out-migration and greater numbers of female-headed households. Both of these articles situate social ideals of male behavior firmly in the distinctive histories of the community under study. 


\section{Gendered Politics, Politics Engendered}

As the compilers of this rich and revealing set of papers, we hope that the insights and analysis will inform the direction of gender studies and Lusophone studies, and especially the intersection of the two areas. Implicitly and explicitly these articles parse gender as women's agency, as masculinity, as relations between men and women, and as representation, sometimes singularly but more often simultaneously. Collectively, these articles reaffirm the salience of gender as a category of experience and analysis, and as a category of social, political, economic, and cultural import. They suggest that if the concept of gender once ran the risk of being ghettoized or marginalized as «women's issues» or special interest politics, that is no longer the case. Instead, these articles quietly insist that to attend to gender, whether in the form of violence and masculinity (Myrttinen); of women's expressive practices (Bastos); of the mutually constructed domestic and professional worlds of the Lisbon business elite (Lima); or in the form of the gendered political discourses and practices of Karanga royalty (Pabiou-Duchamp) is to take up politics in its most intimate and its most public manifestations, often at the same time. The set of papers presented here expand our knowledge of gender and of the Portuguese world in unexpected ways that will benefit all of us.

\section{Fune, 2005 \\ Marissa MOORMAN \\ Indiana University Kathleen SHELDON}

University of California at Los Angeles 